
(2020). Greenwashing Study and Consumers' Behavioral Intentions. Consumer Behavior Review, 4(3), 229-244.

ISSN: 2526-7884

Editor: Prof. Dr. Marconi Freitas da Costa Journal's e-mail: cbr@ufpe.br
Evaluation: Double blind review

Received: March 10, 2020

Accepted: July 05, 2020

\title{
GREENWASHING STUDY AND CONSUMERS' BEHAVIORAL INTENTIONS
}

\author{
Eduardo Roque Mangini ${ }^{1}$ \\ ORCID: http://orcid.org/0000-0002-8363-9226 \\ E-mail: eduardo.mangini@uol.com.br \\ Lucimaura Martins Amaral ${ }^{1}$ \\ ORCID: http://orcid.org/0000-0002-3613-1243 \\ E-mail: lucimaura.martins23@gmail.com \\ Marco Antonio Conejero ${ }^{2}$ \\ ORCID: http://orcid.org/0000-0002-9008-3473 \\ E-mail:marco.conejero@gmail.com \\ Cristiane Sales Pires ${ }^{1}$ \\ ORCID: http://orcid.org/0000-0002-4521-1106 \\ E-mail: cristiane.sales.pires@gmail.com \\ ${ }^{1}$ Instituto Federal de São Paulo, São Paulo, Brazil \\ ${ }^{2}$ Universidade Federal Fluminense, Rio de Janeiro, Brazil
}

Estudo da Prática de Greenwashing e as Intenções Comportamentais do Consumidor

\begin{abstract}
The concern with the environment can change the consumer's view, who seeks eco-friendly products. On the other hand, greenwashing is an act of disguising a weak environmental activity by companies. The aim of this paper is to analyze Greenwashing as a predictor variable of Consumer Perceived Confusion and Trust and how these two constructs influence
\end{abstract}

\begin{abstract}
Resumo
A preocupação com o meio ambiente trouxe mudança no perfil do consumidor, que busca produtos que sejam ecologicamente corretos. Por outro lado, Greenwashing é o ato malicioso de disfarçar uma fraca atuação ambiental das empresas. 0 objetivo do trabalho é analisar o Greenwashing como variável preditora da Confusão Percebida pelo
\end{abstract}


Behavioral Intention. The research method is quantitative, with a cross-section, nonprobabilistic and accessibility sample. The statistical analysis used Structural Equation Modeling. The analyzed product announces that has green marketing approach, but it is considered a deceptive action to deceive the consumer. The proposed hypotheses were statistically supported and as contributions this paper approached the existing relations between greenwashing and purchase intention, showing the importance of the Consumer Perceived Confusion and Trust constructs applied in the conceptual model. The study proved that consumer when perceiving Greenwashing tends not to trust in the product and in the brand. The biggest challenges for companies are taking actions that can represent a concern for the environment since consumers pay more attention to these factors and are less likely to accept the practice of greenwashing.

Keywords: Green Marketing; Greenwashing; Behavioral Consequences

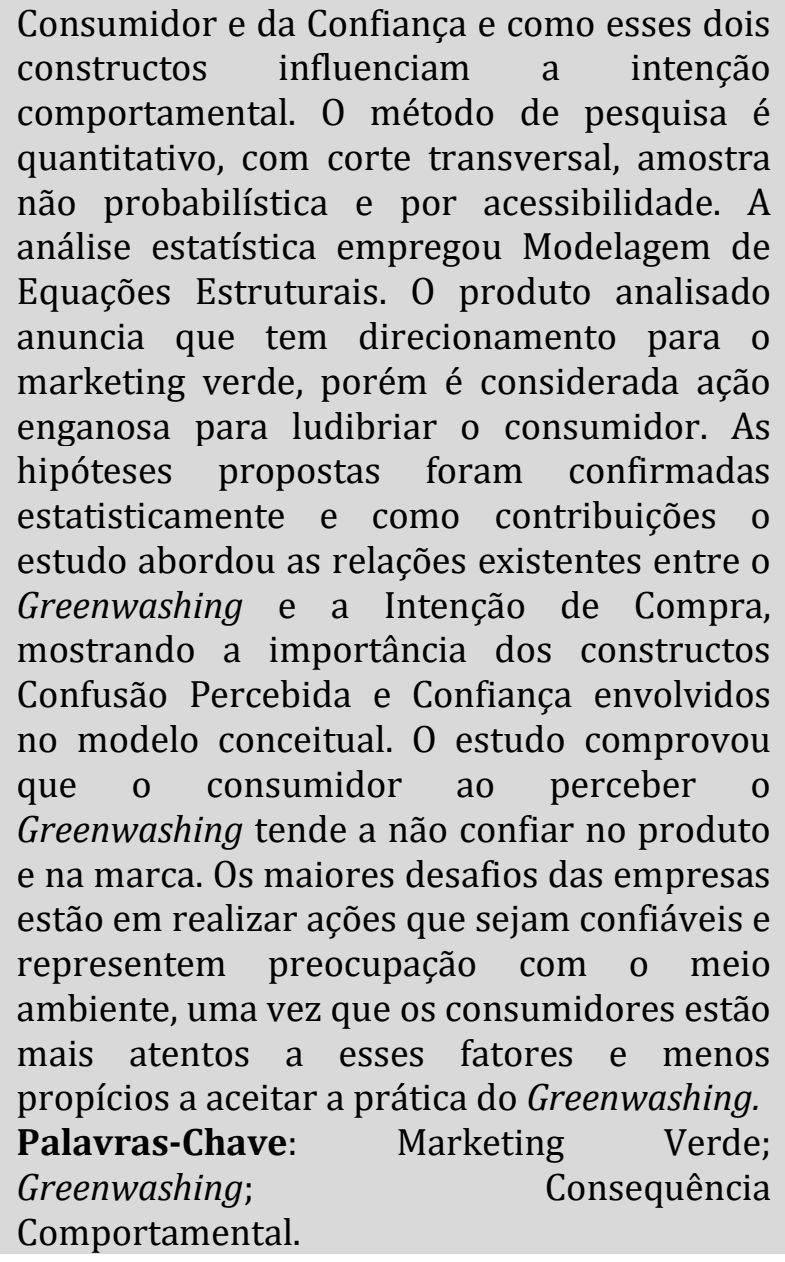

This work is licensed under a Creative Commons Attribution 4.0 International License.

\section{INTRODUCTION}

Environmental concern has changed consumers' profiles. More ecologically aware, they seek products that do not harm nature and are ecologically sustainable. These changes not only impact communication with consumers, as also the consumerism itself, encouraging pro-environmental behavior (Nascimento, 2019). Such attitude is mainly present in Generation Z, whose concern with the environment has been broadly studied. (Pereira et al., 2017). The green marketing comprises a set of activities that pursue satisfying the consumers' needs and wishes, but with the smallest environmental impact possible (Polonsky, 1994). It is also mentioned as the integration of sustainability that embraces marketing aspects (Dangelico \& Vocalelli, 2017).

Green marketing, also known as environmental marketing (Dean \& Pacheco, 2014), is part of a strategic framework and it relates to the commitment and long-term investment in environmental practices and strategies (Papadas et al., 2017). Considering the strategy of green marketing, it is crucial that the company establishes an adequate marketing mix with the development of green products, environmental segmentation and positioning, as well as the suitability of waste, less invasive logistics and choosing communication that privileges ecologically friendly resources (Groening et al., 2018). Green marketing is used as a strategic tool which increases the company's brand value to the consumer, beyond being used to generate competitive advantage (Groening et al., 2018; Simão \& Lisboa, 2017).

Moreover, green marketing includes initiatives, which not only benefit the ecologically aware consumer, but also other practices such as reduction of environment impacts and pollutants, commitment to the environment protection, and use of sustainable resources (Polonsky, 2011). Green 
marketing considers both communication policies and strategies focused on obtaining competitive advantage on products and services in comparison with competitor brands and highlights the company's ecological and sustainable role (Hasan \& Ali, 2015). Considering consumers thoughts and behavior regarding non-sustainable products, companies have sought to adapt in order to satisfy them, using the advantages green marketing offers (Lu et al., 2013). As a result, the company increases market share, improves image and obtains competitive positioning consolidation (Dias, 2011).

As the consumers' concern with the environment has risen, companies have been using the "green marketing" label as a way to satisfy them and promote the brand, giving the false impression as a sustainable and environmental friendly company (Parguel et al., 2011). These actions do not follow the green marketing requirements, creating doubts, affecting trust and purchase intention, and generating negative buzz (Leonidou \& Skarmeas, 2015). This practice, known as Greenwashing, is considered a marketing, sales, and media relations actions, done by companies to broadcast their image as oriented for environment preservation. Such practices, however, are considered harmful for the environment (Braga Junior et al., 2019).

Not only does Greenwashing include misleading information, but, mainly, the malicious act of increase the importance of irrelevant facts and disguises the weak environmental performance. The increase of interest in green products also leads to the increase of Greenwashing (Akturan, 2018), because in a World where Green Economy and the importance of good sustainability practices grow for consumers, looking green is particularly important (Martínez, 2015). Studies show the negative effect of Greenwashing and indicate the need to verify these effects in other cultures and products (Akturan, 2018; D. Wang et al., 2020; H. Wang et al., 2019). For those reasons, it was identified the need to conduct a research to understand the direct influence of Greenwashing on costumers' confusion and trust and how that affects behavioral intention, which was analyzed based on a beer brand.

Within this context, this paper has as research problem the following question "What is the influence of Greenwashing on a product's behavioral intention with ecological appeal?". To answer this question, the research had as objective to analyze Greenwashing as a predictor variable in Consumer Confusion and Trust and how the two constructs influence the Consumer Behavioral Intention. From those, there is a ramification into specific objectives: (1) to verify the influence of Greenwashing in Consumer Confusion; (2) to evaluate the effect Greenwashing over Consumer Trust; (3) to understand the impact of Consumer Confusion on Consumer Trust; (4) to evaluate the mediation effect of Consumer Confusion in the relation between Greenwashing e Trust, (5) to measure the relation between Trust and Purchase Intention.

\section{THEORETICAL FRAMEWORK}

\section{Green Marketing}

Green Marketing has become a business trend as it aims to increase value in consumers' perspective (Lu et al., 2013). Although it is seen as a 21st century perspective, the practice started in the 1960s with the understanding natural resources are limited (Zinkhan \& Carlson, 1995). More than a trend, green marketing has gained space among organizational practices as consumers started acquiring eco-friendly product (Paço et al., 2009). Lima et al. (2019) also affirm that consumers seek sustainable products, but their use is below expected.

Green Marketing is all practices or activities that focus on attending human needs and desires by impacting the environment as little as possible (Polonsky, 1994). It is also considered a set of activities that seek to reduce negative impacts, either socially or ecologically, in means of production, products and services considered environmentally friendly (Peattie, 2001). Furthermore, Green marketing can be seen as a way of differentiating the products whose consequences in companies consist in generating competitive advantage, and social and environmental responsibility in their products and services (Chen \& Chang, 2013). It can be defined as a general system or managerial process responsible for the identification and satisfaction of clients' needs in a, profitably and sustainably way (Li et al., 2018). Nevertheless, Papadopoulos et al. (2010) alerted that creation of sustainable marketing strategies is a difficult process due to the lack of environmental knowledge 
consumers have and low trust in companies concerning the protection of environment. The strategies and green consumerism are part of Green Marketing (Zhu \& Sarkis, 2006).

On a consumerist perspective, green products are those which preserve natural resources (Lopes \& Pacagnan, 2014). Such eco-friendly products have gained space in consumers' lives (Montague \& Mukherjee, 2010), which can be confirmed by Smith e Brower (2012) who affirm that environmentally friendly products have shown to be a highly profitable market. Another point to be highlighted is that corporate image leads to the increase of market share and the generation of consumer's loyalty (Montague \& Mukherjee, 2010), and green products can boost a country's development (Fraccascia et al., 2018).

Eco-Friendly products and services, which belong to Green Marketing, lead consumers and companies to raise their environmental awareness (Lu et al., 2013; Zinkhan \& Carlson, 1995). Thus, consumers have progressively become important for the development of sustainable product that use natural resources efficiently with low environmental impact (Ghoshal, 2011). In fact, green consumers can be considered driver of business practices and help economic development (Papadopoulos et al., 2010). However, some companies modify their products, so they look, but not actually become "ecofriendly" (Montague \& Mukherjee, 2010), which is known as Greenwashing. This term can be connected to a marketing or communication action a company does to look environmentally correct instead of truly being it (Brønn, 2011).

\section{Greenwashing}

Greenwashing consists in misleading advertisement, marketing or public affairs companies do to project an environmentally oriented image even if their actions are considered harmful (Parguel et al., 2011). The term was created in 1986 when American activist Jay Westerveld criticized hotel industry actions, which claimed to use towels to save the environment, while had fragile policies in other business aspects (Romero, 2008).

Greenwashing can be presented as ambiguous, shallow, vague or with lack of information to be confirmed as green marketing (Grove \& Kangun, 1993) or even use images, symbols, slogans aiming to show ecological properties that do not exist (Parguel et al., 2015). In addition, Greenwashing highlights irrelevant facts to disguise the weak environmental performance (Akturan, 2018), which reflects on consumers' behavior. Another point worth mentioning is that this practice is connected to Green Economy and sustainability, which grows in consumers' intentions, consequently creating the impression that "looking green" is more important (Berrone et al., 2015). However, excessive information can be misleading and cause consumers' confusion (Turnbull et al., 2000). Either for ambiguity or excessive or lack of information, we call Greenwashing when there is wrong interpretation about products, and companies mislead their consumers on what it a green product is (Mitchell et al., 2005). Considering that Greenwashing exaggerates on market appeals, it is possible to believe in the first hypothesis H1: Greenwashing has positive impact on Consumers' Confusion.

In relation to consumers' behavior, Greenwashing reflects on the skepticism (Rahman et al., 2015), trust and perceived risk (Chen \& Chang, 2013), brand and purchase intention (Akturan, 2018). Trust can be defined as a relationship between two parts in which one believes on the other's integrity (Sirdeshmukh et al., 2002). It is a relationship with an individual or a group connected to a relational orientation (Young, 2006) and based on the hope that the second part will satisfy what was previously established (Colquitt et al., 2007; Moorman et al., 2011). Trust is a construct that possesses both emotional and cognitive appeal (McAllister, 1995; Sirdeshmukh et al., 2002; Terres et al., 2015) and it is a predictor of behavior consequences, such as satisfaction and loyalty (Martínez, 2015). As pointed out by Braga Junior et al. (2019) consumers suspect the company when there is tendency for the product to be manipulated in order to be considered sustainable, creating an inverse relationship between Greenwashing and trust. According to the exposed, it is possible to conceive a second hypothesis H2: Greenwashing has a negative impact on Consumers' Trust.

Greenwashing harms consumers' trust and it is related to consumers' confusion and perceived risk on green products (Chen \& Chang, 2013). Consumers' confusion emerges from a company's doubtful communication and practices that claim to be sustainable, when, in fact, are not (Montague \& 
Mukherjee, 2010). As a result, these practices reduce attention to green products (Parguel et al., 2011). If a consumer is confused about a certain product, it is unlikely he will trust it (Mitchell \& Papavassiliou, 1999). The skepticism caused by the companies' communication and behavior leads consumers in to believing in the benefits and attributes of green products (Leonidou \& Skarmeas, 2015). Hence, perceived and experienced confusion by consumers has negative impact on trust (Matzler et al., 2011) and, adding the ecological component, the more confused the consumers are, the less they trust the company or the product (Chen \& Chang, 2013). Given this discussion, another hypothesis is established H3: Confusion perceived by consumer has a negative impact on Trust.

The relationship between Greenwashing and consumers' trust, although direct, is also possible indirectly, mediated by perceived confusion. As Greenwashing creates confusion and reduces trust, it can be considered a fraud (Kurpierz \& Smith, 2020). When considering that confusion has negative impact on trust (Mitchell et al., 2005), it is possible to predict a mediated relationship, in which Greenwashing is an independent variable, trust is a dependent variable, and confusion is a mediator variable (Chen \& Chang, 2013), whose hypothesis is H4: The relationship between Greenwashing and Trust is mediated by Consumers' Confusion.

The development of a green and sustainable image helps companies to improve their own images (Yadav \& Pathak, 2017). According to Rahman, Park e Chi (2015) green image can increase consumers' purchase intentions in a company, possibly resulting in greater satisfaction and loyalty. Such image creates trust, which is the intention of accepting something based on positive behavior expectations or intentions of the second part of the commercial involvement (Rousseau et al., 1998). Green Trust, generated from the image a company or a product transmits, has implications on satisfaction and loyalty to green products (Martínez, 2015). As stated by Chen e Chang (2013), reduction or lack of green trust affects purchase intentions in green products, creating difficulties for the consumer to identify real green products and preventing them from buying eco-friendly products. Another important fact is that consumers stop believing in green marketing, even if true (Correa et al., 2018). Thus, it is necessary for companies to allow consumers to have enough and reliable information to create value, and so, strengthen the relationship between trust and positive purchase intention (Akturan, 2018; Chen \& Chang, 2013). From that, it is created another hypothesis H5: Trust has positive impact on Purchase Intention.

\section{Conceptual Model}

Greenwashing has been practiced by several companies, including Brazilians. The reflection of these practices is observed in consumers' behavior, and it was possible to establish the research model in figure 1 from the theorical framework.

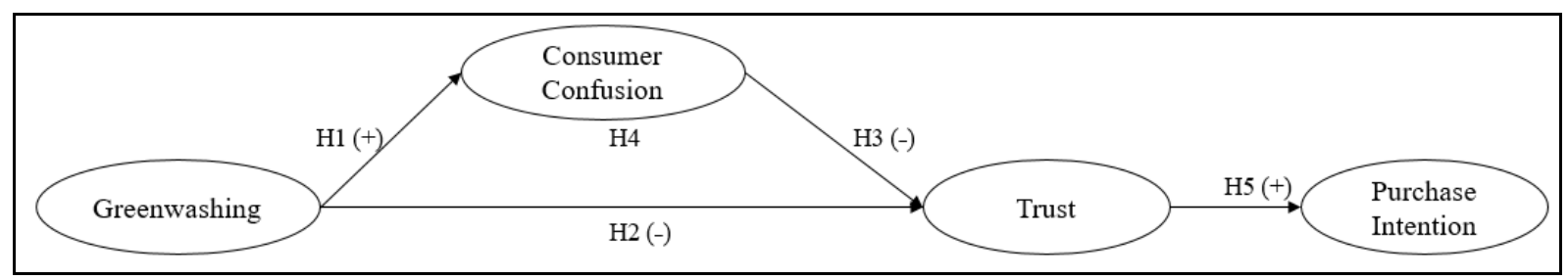

Sources: developed by authors.

Figure 1: Conceptual Model

\section{METHOD}

This study is based on quantitative research, with descriptive perspective and structured on the development of hypothesis (Cooper \& Schindler, 2016). This research focus on the description of a phenomenon, which allows making inferences, and discovering new possible associations with different variables (Cooper \& Schindler, 2016; Malhotra, 2019). This is a cross-sectional study as data was collected within a specific period and statistically summarized (Hair; Babin ; Money \& Samouel, 
2005). The data collection method consists on a survey that seeks to obtain information through questionnaires distributed to a sample of the population (Edmonds \& Kennedy, 2017).

Structural Equation Modeling (SEM) was used to analyze the statistics, as the data do not follow multivariate normal distribution or need a more complex model (Ringle et al., 2014). To properly dimension the size of the sample, the software G-Power was used, considering the number of predictors (2), $15 \%$ of effect size, $5 \%$ of error probability and $80 \%$ of statistical power. Although the minimum sample was of 68 valid responses, 129 answers were collected, which assumes a high statistical power. Comparing the size of the sample carried out and calculated (Table 1), it is possible to notice the increase of statistical power (from $80 \%$ to $98 \%$ ) and sensibility ( $f^{2}$ from 0,15 to 0,07 ) of the following statistical analyzes.

Table 1

Sample Calculation

\begin{tabular}{lccc}
\hline Adopted Assumptions & A priori & Post hoc & Sensibility \\
\hline Effect size $\left(\mathrm{f}^{2}\right)$ & 0,15 & 0,15 & 0,07 \\
Level of significance $(\alpha)$ & 0,05 & 0,05 & 0,05 \\
Power $(1-\beta)$ & 0,80 & 0,98 & 0,80 \\
Number of predictors & 2 & 2 & 2 \\
Sample Size & 68 & 129 & 129 \\
\hline
\end{tabular}

Source: carried out by authors using the software G-Power.

The sample is classified as non-probabilistic and by accessibility. The questionnaires were distributed in a big shopping center in the countryside of São Paulo, where there are many points of sales and consumption of craft beers. Questionnaires from people who do not drink beer have been discarded and did not take part on the sample used for the statistical analysis.

The scales used for data collection follow the validation process suggested by DeVellis (2003). To measure the constructs, Greenwashing, Consumers' Confusion and Trust, the scales proposed by Chen e Chang (2013) were used, and to investigate the Purchase Intention, Akturan's (2018) scale was used. The data collection instrument can be found in the Appendix, having the name and image of the brand deleted by ethical matters. Using the software SPSS (Statistical Package for the Social Sciences), it was noticed that the data are not normally distributed (Kolmogorov-Sminorv test), which reinforces the need for using the Structural Equation Modeling technique, and the software SmartPLS 3.2.8.

\section{ANALYSIS AND DISCUSSION Data Analysis}

For the data collection, a beer brand that develops green marketing was chosen. The referred beer brand makes it clear both in the secondary packaging and the label, that it is an "environmentally friendly" company. The data collection occurred between the months of September and October of 2019. 146 answers were collected, although only 129 were considered valid. The discard of 17 responses was due to the fact the respondents did not consume the analyzed product. Of the total respondents (129), most were female, with 71 valid answers, which corresponds to $55 \%$ of the sample total. Only 4 people did not wish to answer this question. Most are single (62\%) followed by married $(31,8 \%)$. The respondents who have children consist in a segment of 43 respondents and correspond to $33,3 \%$ of the survey total participants. The respondents, which had already bought the analyzed beer, correspond to just over $15 \%$.

After evaluating if the data were adherent to the normal distribution curve following the Kolmogorov-Sminorv test made on software SPSS, Structural Equation Modeling was carried out using the software SmartPLS 3.2.8. For the adjusted model it was necessary the withdrawal of items from latent variables with values below 0,40 , remaining the items that presented outer loadings above 0,70 (Hair et al., 2017). One item only with outer loading below 0,70 was maintained to ensure the effectiveness of the construct Greenwashing content. 
Initially, the presented SRMR (Standarized Root Mean Square Residual) value of 0,08 was verified, limit established by Henseler, Hubona and Ray (2016), which certifies a good model adjustment. Afterwards, the multicollinearity verification took place, with a posterior evaluation of the measuring model, with internal data consistency analysis, convergent validity and discriminant validity. The VIF values (Variance Inflation Factor) varied from 1,00 to 1,32, following the recommendation of Hair, Sarstedt, Ringle e Gudergan (2018) whose value must be below 3,5. In table 2, obtained data with the evaluation of PLS Algorithm is presented. In the AVE (Average Variance Extracted) it is possible to affirm the items present a convergence, in other words, the relation between same construct measurements is elevated approximately with the same magnitude (Fornell \& Larcker, 1981).

It means the construct indicators share (converge) a proportion of the common variance (Hair et al., 2009). It also means the representation of a set of indicators in a subjacent construct, demonstrated by its unidimensionality (Henseler et al., 2009). The AVE value must be above 0,50 (Ringle et al., 2014). Besides the Convergent Validity, measured by the AVE value, it is necessary to assess the internal consistency, used to such Composite Reliability. This index value is higher than the reference value (Hair et al., 2017), which confirms the internal consistency.

The confirmation of the Discriminant Validity is given by the data analysis of the HeterotraitMonotrait Ratio (HTMT), which cannot be higher than 0,85 (Hair et al., 2017) and the root square of AVE (Fornell-Larcker criteria). By the test results, it is corroborated the existence of the Discriminant Validity in the model (Henseler et al., 2015).

Table 2

Data Consistency, Convergent and Discriminant Validity

\begin{tabular}{|c|c|c|c|c|c|c|}
\hline \multirow{3}{*}{$\begin{array}{c}\text { Latent } \\
\text { Variable }\end{array}$} & \multirow{3}{*}{ Indicators } & \multicolumn{2}{|c|}{$\begin{array}{c}\text { Convergent } \\
\text { Validity }\end{array}$} & \multirow{2}{*}{$\begin{array}{l}\text { Internal } \\
\text { Consistency } \\
\text { Reliability } \\
\text { Composite } \\
\text { Reliability }\end{array}$} & \multirow{2}{*}{\multicolumn{2}{|c|}{$\begin{array}{l}\text { Discriminant Validity } \\
\text { Root } \\
\text { Square } \\
\text { of the } \\
\text { AVE }\end{array}$}} \\
\hline & & Loading & (AVE) & & & \\
\hline & & $>0,70$ & $>0,50$ & $>0,70$ & & $\begin{array}{c}\text { Confidence } \\
\text { interval does } \\
\text { not include } 1\end{array}$ \\
\hline \multirow{4}{*}{ Trust } & GT2 & 0,829 & \multirow{4}{*}{0,62} & \multirow{4}{*}{0,87} & \multirow{4}{*}{0,79} & \multirow{4}{*}{$\operatorname{sim}$} \\
\hline & GT3 & 0,796 & & & & \\
\hline & GT4 & 0,770 & & & & \\
\hline & GT5 & 0,753 & & & & \\
\hline \multirow{3}{*}{$\begin{array}{l}\text { Consumer } \\
\text { Confusion }\end{array}$} & GCC1 & 0,816 & \multirow{3}{*}{0,56} & \multirow{3}{*}{0,79} & \multirow{3}{*}{0,75} & \multirow{3}{*}{$\operatorname{sim}$} \\
\hline & GCC2 & 0,703 & & & & \\
\hline & GCC6 & 0,716 & & & & \\
\hline \multirow{2}{*}{ Greenwashing } & GW3 & 0,919 & \multirow{2}{*}{0,61} & \multirow{2}{*}{0,75} & \multirow{2}{*}{0,78} & \multirow{2}{*}{$\operatorname{sim}$} \\
\hline & GW4 & 0,619 & & & & \\
\hline \multirow{4}{*}{$\begin{array}{l}\text { Purchase } \\
\text { Intention }\end{array}$} & IC1 & 0,783 & \multirow{4}{*}{0,68} & \multirow{4}{*}{0,89} & \multirow{4}{*}{0,82} & \multirow{4}{*}{$\operatorname{sim}$} \\
\hline & IC2 & 0,855 & & & & \\
\hline & IC3 & 0,853 & & & & \\
\hline & IC4 & 0,804 & & & & \\
\hline
\end{tabular}

Source: Research Data

The coefficient of determination, $R^{2}$ and adjusted $R^{2}$ values unfold the existence of a great effect in the latent variables Consumer Confusion $\left(R^{2}=0,242\right.$ e adjusted $\left.R^{2}=0,236\right)$, Trust $\left(R^{2}=0,213\right.$ 
and adjusted $\left.R^{2}=0,200\right)$ and Purchase Intention $\left(R^{2}=0,281\right.$ and adjusted $\left.R^{2}=0,275\right)$. Meaning that the regressions are well adjusted and there is predictive power, for they represent the variety quantity in the endogenous construct which is explained by all the exogenous constructs connected to them (Cohen, 1988).

As for the Cohen indicator $\left(\mathrm{f}^{2}\right)$, which analyzes the size of effect, it takes into consideration the Explained and Unexplained Variances. The aim of this indicator refers to the usefulness assessment of each construct so that the model adjustment occurs. The reference values are $0,02,0,15$ or 0,35 indicate weak, moderate, or substantial influence of an exogenous latent variable in a certain endogenous latent variable (Hair et al.,2017). The $\mathrm{f}^{2}$ value between Greenwashing and Consumer Confusion can be considered of an elevated expression for it presented a value of 0,320 as well as the relation between Trust and Purchase Intention $\left(\mathrm{f}^{2}=0,391\right)$, while the others are classified as weak (Greenwashing $\rightarrow$ Trust - $\mathrm{f}^{2}=0,077$; Consumer Confusion $\rightarrow$ Trust - $\mathrm{f}^{2}=0,061$ ). Therefore, the predictive validity in hypothesis $\mathrm{H} 1$ and $\mathrm{H} 5$ are substantial.

Table 3 presents the hypothesis, the structural model and the VIF, $\mathrm{f}^{2}, \mathrm{R}^{2}$ and adjusted $\mathrm{R}^{2}$ values, which validate the measurement model adjustment.

Table 3

VIF, $\mathrm{f}^{2}, \mathrm{R}^{2}$ and adjusted $\mathrm{R}^{2}$ values.

\begin{tabular}{llcccc}
\hline Hypothesis & Structural Model & VIF & $\mathbf{f}^{\mathbf{2}}$ & $\mathbf{R}^{\mathbf{2}}$ & $\mathbf{R}^{\mathbf{2}}$ adjusted \\
\hline H1 & Greenwashing $\rightarrow$ Consumer Confusion & 1 & 0,320 & 0,242 & 0,236 \\
H2 & Greenwashing $\rightarrow$ Trust & 1,32 & 0,077 & & \\
H3 & Consumer Confusion $\rightarrow$ Trust & 1,32 & 0,061 & 0,213 & 0,200 \\
H5 & Trust $\rightarrow$ Purchase Intention & 1 & 0,391 & 0,281 & 0,275 \\
\hline
\end{tabular}

Source: Research Data

On figure 2, which represents the adjusted model, it is possible to notice the outer loadings values, the path coefficient (beta) and the $\mathrm{R}^{2}$ value, represented in the dependent variables.

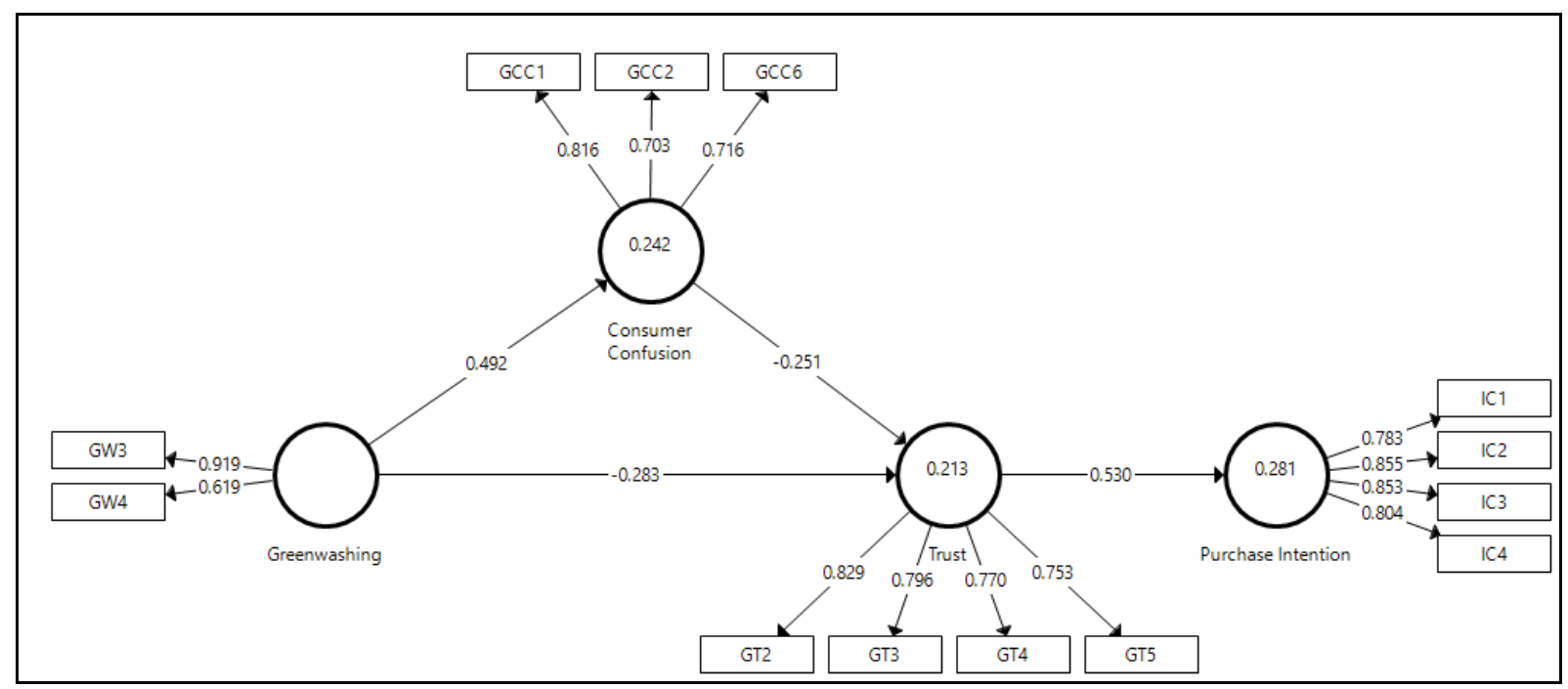

Source: Research Data

Figure 2: Adjusted Model

Along the measurement model adjustment, the next step consisted in the evaluation of the structural model by using Basic Bootstrapping, that randomly draws several subsamples and model estimation (Hair et al., 2009). The causal relation between the constructs is measured by Student test, 
where the coefficient values work to identify the relation between the constructs, depending on the significance level (Hair et al., 2017). The t-estimated values are associated to the path coefficients, via Bootstrapping, which in this article used 5000 samples. Besides providing the $t$ test, it also supplies the structural coefficient ( $\beta$ ), standard error and p value (Ali et al., 2018).

Table 4 presents the values, which allowed affirming that, the four proposed hypotheses were considered as being significant and supported. As theorized, hypothesis $H 1(\beta=0,492$ and test $t=$ $6,698)$ and $H 5(\beta=0,530$ and test $t=9,380)$ present a positive and significant relation for they display a positive structural coefficient, t test above 3,29 and significant at $0,1 \%$. As for hypothesis $\mathrm{H} 2$ and $\mathrm{H} 3$ present $\beta=-0,283$ between Greenwashing and Trust and $\beta=-0,251$ between Consumer Confusion and Trust, but with a significant statistic value (H2 t test $=2,890$ and $\mathrm{H} 3 \mathrm{t}$ test $=3,087$ ).

Table 4

Tests and Values

\begin{tabular}{clcccccc}
\hline Hypothesis & Structural Model & $\begin{array}{c}\text { Structual } \\
\text { Coefficient } \\
(\boldsymbol{\beta})\end{array}$ & $\begin{array}{c}\text { standard } \\
\text { error }\end{array}$ & $\begin{array}{c}\text { t } \\
\text { value }\end{array}$ & $\begin{array}{c}\text { p value } \\
\text { Hypothesis } \\
\text { test }\end{array}$ \\
\hline H1 & Greenwashing $\rightarrow$ Consumer & Confusion & 0,492 & 0,073 & 6,698 & 0,0001 & Supported \\
H2 & Greenwashing $\rightarrow$ Trust & $-0,283$ & 0,098 & 2,890 & 0,004 & Supported \\
H3 & Consumer Confusion $\rightarrow$ Trust & $-0,251$ & 0,081 & 3,087 & 0,002 & Supported \\
H5 & Trust $\rightarrow$ Purchase Intention & 0,530 & 0,057 & 9,380 & 0,0001 & Supported \\
\hline
\end{tabular}

Critical Values for $\mathrm{t}_{(129)}={ }^{*} \mathrm{p}<0.1 \%=3.29 ;{ }^{* *} \mathrm{p}<1 \%=2.57 ;{ }^{* * *} \mathrm{p}<5 \%=1.96$

Source: Data Research

Figure 3 represents the structural model in relation to the latent variables and the t test values.

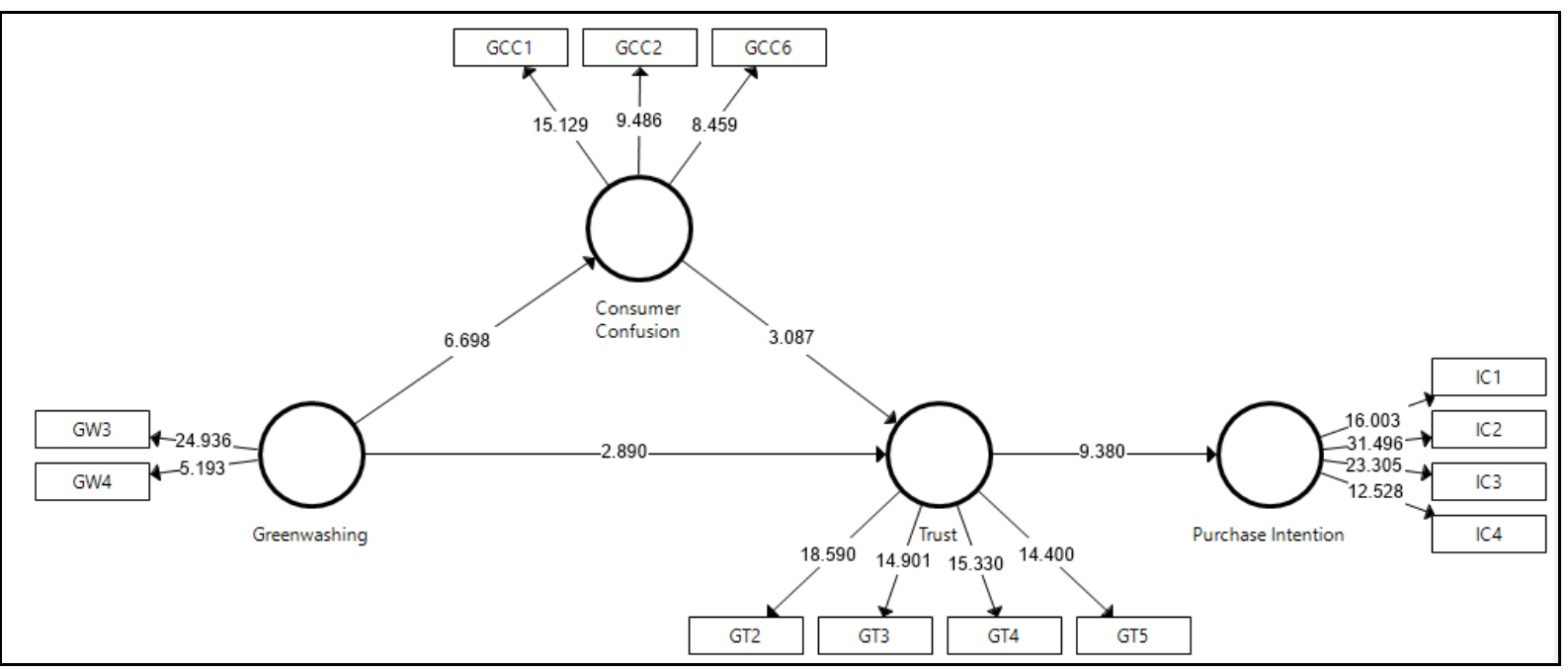

Source: Data Research

Figure 3: Model with t test values.

The mediation occurs when another construct interferes in the relation established between two variables (Baron \& Kenny, 1986). The mediator effect (also known as indirect effect or mediation) involves a third variable, whose intermediate part is a relation between Independent Variable (IV) and Dependent (DV) (Nitzl et al., 2016). Figure 4 shows the mediated relation and it is worth highlighting that, a change in construct IV will affect Mediator M, which will affect construct DV (Hair et at., 2017). 


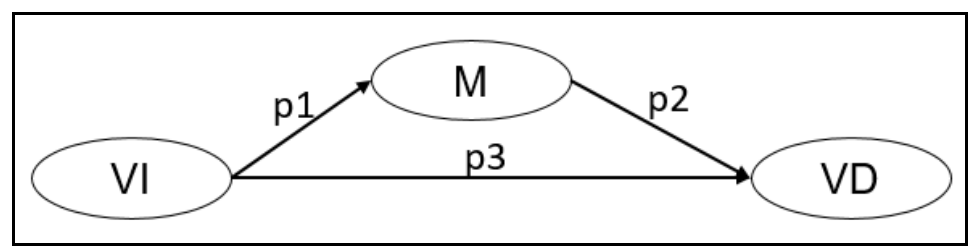

Source: Nitzl et al. (2016)

Figure 4: General Mediation Model

From the path coefficient analysis (p1, p2 and p3) and the possible relations between these coefficients, it is possible to classify the mediation in five different types as illustrated by figure 5 . The non-mediation is characterized by "Direct-Only" and "No Effect" types. The mediation can be of the Indirect-Only, Competitive or Complementary types (Nitzl et al., 2016; Zhao et al., 2010).

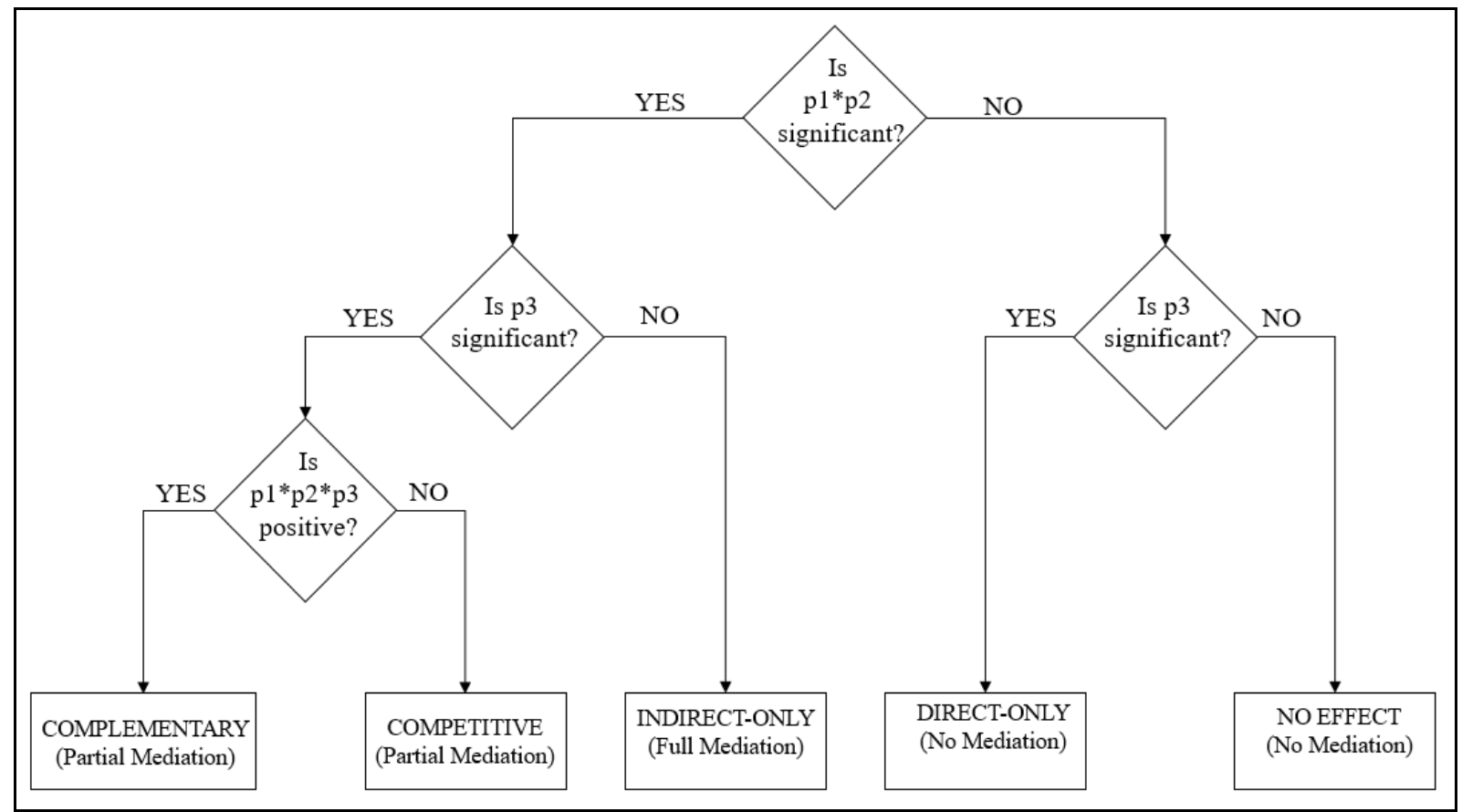

Source: Zhao et al. (2010)

Figure 5: Mediation Types

By adopting the Zhao et al. (2010) model to evaluate the existence of the Consumer Confusion Mediation in the Greenwashing and Trust relation, it is necessary to verify the Total, Direct and Indirect Effect in this relation. The Total Effect, which compiles both Direct and Indirect effects, is provided by the Bootstrapping procedure and the analysis of these effects are presented in table 5 .

Table 5

Total, Direct and Indirect Effect in the Greenwashing and Trust relation

\begin{tabular}{|c|c|c|c|c|c|}
\hline \multicolumn{2}{|c|}{ Total Effect } & \multicolumn{2}{|c|}{ Direct Effect } & \multicolumn{2}{|c|}{ Indirect Effect } \\
\hline $\begin{array}{c}\text { Estructural } \\
\text { Coefficient }(\beta)\end{array}$ & t test & $\begin{array}{c}\text { Estructural } \\
\text { Coefficient }(\beta)\end{array}$ & t test & $\begin{array}{c}\text { Relation between } \\
\text { Coeficients }\end{array}$ & Valor \\
\hline$-0,406$ & 4,510 & $-0,283$ & 2,890 & $(\mathrm{GW} \rightarrow \mathrm{GCC}) *(\mathrm{GCC} \rightarrow \mathrm{GT})$ & $-0,123$ \\
\hline
\end{tabular}

Source: Data Research 
By evaluating the path coefficients $(\mathrm{p} 1=0,492 ; \mathrm{p} 2=-0,251 ; \mathrm{p} 3=-0,283$ ) and the $\mathrm{p}$ value (significant at 1\%), it is possible to confirm that the Consumer Confusion plays the part of a Mediator variable in the Greenwashing and Trust relation. As in the proposed model by Zhao et al. (2010) it is possible to state that it is a matter of Complementary Partial Mediation, for the path coefficient product is positive and each path is significant at 1\%. Thereby, table 6 presents the data that allows affirming Hypothesis 4 is supported.

Table 6

Hypothesis H4 over Mediation

\begin{tabular}{clccccc}
\hline Hipothesis & Mediator & $\begin{array}{c}\text { GW and } \\
\text { GCC }\end{array}$ & GCC and GT & $\begin{array}{c}\text { GW and } \\
\text { GT }\end{array}$ & $\begin{array}{c}\text { Type of } \\
\text { Mediation }\end{array}$ & $\begin{array}{c}\text { Hypothesis } \\
\text { test }\end{array}$ \\
\hline \multirow{2}{*}{ H4 } & Consumer Confusion & Significant & Significant & Significant & $\begin{array}{c}\text { Partial Mediation } \\
\text { (Complementary) }\end{array}$ & Supported \\
\hline
\end{tabular}

Source: Data Research

\section{Discussion of Results}

The analyzed product, in its packaging and label, announces its strategic and marketing direction to the green marketing with the intention of increasing its market share. Such perspective confirms the statement of Lu, Bock and Joseph (2013) regarding the product consumption that present the environmentally friendly connotation. The consumers seek products that have a green appeal as pointed out by Paço et al. (2019) and Lima et al. (2019). Although, the packaging and label are not sufficient to affirm the product is, in fact, sustainable from the ecological point of view and might be considered as a deceptive action to deceive the consumer (Parguel et al., 2011, 2015).

The use of the environmental appeal as proposed by the company and presented in the marketing communication provides information that generates confusion for the consumer (Akturan, 2018; Rousseau et al., 1998). Even more so when the marketing communication elucidates a low involvement message, which aggravates the Greenwashing perception and makes the consumers reject the product as well as the brand and the company (Braga Junior et al., 2019). Exaggerated information, used as green marketing appeal, provided the creation of confusion for the consumer, in other words, the greatest Greenwashing perception generates a greater confusion for the consumer. This fact validates Turnbull's et al. (2000) statements about the lack of marketing information interpretation that generates confusion. In doing so, it was possible to prove that the inadequate usage of ecological appeal causes Confusion detected by the Consumer, a fact that is authenticated by Hypothesis $\mathrm{H} 1$ result and sustained by Chen and Chang (2013). Through the analysis of the structural coefficient $(\beta=0,492)$, it is possible to affirm that there is a positive and significant ( $t$ test $=6,698, p$ value $<0,0001$ ) relationship between the Greenwashing practice and the confusion detected by the consumer.

In analyzing the Trust predecessors, it was possible to check that, both Greenwashing practice and the confusion detected by the consumer have a negative influence. This fact is endorsed by the structural coefficients that are negative. On the one hand, green marketing and communication bring about a trust increase and an inclination for the acquirement of goods and services considered ecofriendly (Bailey, Mishra, \& Tiamiyu, 2014; Paço, Shiel, \& Alves, 2019), on the other hand, Greenwashing has the opposite effect (Chen \& Chang, 2013). Trust is a construct defined as a relation in which a part ensures or hopes the other part will fulfill what was proposed or determined (Sirdeshmukh et al., 2002). Greenwashing is a corrosive practice of trust formation as displayed by Chen and Chang (2013) and Braga Junior et al. (2019) whose consequences remain in the product rejection and affects both satisfaction and loyalty as recommended by Martínez (2015). Hypothesis $\mathrm{H} 2$ $(\beta=-0,283$, $t$ test $=2,890$ and significant at $1 \%)$ indicates the communication and slogans are seen as Greenwashing and negatively stimulates the creation of Trust. Additionally, the Confusion the consumer experiences has a negative influence on the Trust formation (Matzler et al., 2011). This explains the marketing information that exaggerate and provoke this confusion will indirectly affect in 
the trust generation. As quoted by Chen, Huang, Wang and Chen (2018), Greenwashing creates skepticism, which will directly affect the consumer's decision-making, as confirmed by Goh and Balaji (2016). When analyzing the results of Hypothesis H3, it is possible to notice that the structural coefficient is negative, which shows that the more Confusion experienced by the consumer, the less he trusts the product.

In the proposed model, the Trust has as predictors both the Greenwashing practice and the Confusion detected by the consumer, both with negative structural coefficients. Considering the Greenwashing is also a predictor of the Consumer Confusion, the latest acts as a Mediator variable. The relation Greenwashing - Trust presents partial mediation of the Complementary type. It is not a complete mediation, for the Greenwashing - Trust relation is statistically significant, and the indirect path also shows itself significantly. In order to verify if Hypothesis 4 is supported, the Zhao et al. (2010) procedure was used, which takes into consideration the path coefficient of the analyzed relation. Coefficient $p 1(\beta=0,492)$ multiplied by coefficient $p 2(\beta=-0,251)$ has a significant result, since both coefficients are significant and this indicates that there is a mediation. The second step of the analysis consists of verifying the type of effect when evaluating if $\mathrm{p} 3(\beta=-0,283)$ is significant and by doing so, it is established as a Partial Mediation. When multiplying the coefficients $\mathrm{p} 1{ }^{*} \mathrm{p} 2 * \mathrm{p} 3$ it is possible to certify the result is positive, therefore, it is a Partial Mediation of the Complementary type. It implies that the Trust formation is a result of the Greenwashing action as well as the Confusion by the consumer. Both direct and indirect relations have the same direction, which allows affirming that part of the Greenwashing effect in the Trust is measured by Confusion while another part comprises itself of the direct effect.

Lastly, Hypothesis H5, proposes that the bigger the trust the consumer develops, the greater the intention to buy the product as stated by Chen and Chang (2013), Martínez (2015) and Akturan (2018). With a 0,53 coefficient and test of 9,380, the positive relation is statistically significant. In other words, from the generation of consumer trust, there is a high probability that the product purchase occurs, as the trust is a strong predictor of the Purchase Intention, fact proven by the $\mathrm{f}^{2}$ value. It allows us to state that, the consumer who develops trust in a product considered as environmentally friendly tends to develop the purchase intention (Akturan, 2018; Paço et al., 2019).

\section{CONCLUSIONS}

The consumer has been increasingly concerned with the environment (Smith \& Brower, 2012) and this behavior change makes them want to purchase more sustainable products (Lu et al., 2013), by seeking those that are harmless to nature (Goh \& Balaji, 2016; H. Wang et al., 2019). This market share becomes more and more interesting, especially with generation "Z" as stated by Pereira et al. (2017). As a result, the number of companies using the term green marketing increases, in order to establish a greater bond with the consumer and strengthen their image before them and the media (Zhang et al., 2018). Nevertheless, some of these companies have not adopted this practice in an ethic and correct manner, trying to deceive the consumer, practice also known as Greenwashing (Parguel et al., 2015).

It was possible to verify that the analyzed product presents in its label and package a strategic orientation focused on green marketing. It demonstrates that the company intends to improve its market share by exploring the consumer trend in purchasing products with ecological appeal. However, the provided information by the company causes confusion and creates a suspicion in the consumer. In a situation where skepticism is increasingly part of the consumer's life, the decisionmaking process is harmed. These are Greenwashing characteristics, that when noticed by the consumers, affect directly the truste in relation to the product and the purchase intention as stated by Akturan (2018), which connects the green brand in the relation with the buying behavior. The analyzed product tries to create this green brand by recalling it as an ecological beer, although it uses this practice without the support and proof of the green marketing practice.

The indicated happens in Brazil due to lack of inspection of the responsible and regulatory bodies that must supervise and reduce the space for misleading advertising and trivialization of the term sustainability, which may end up deceiving the consumer. Thus, it is of great importance to fight the Greenwashing practice, and in Brazil, CONAR (National Council of Self-Regulation in Advertising) is 
the council that regulates the publicity actions. Appendix U of the Brazilian Advertising Self-regulation Code declares "Conar encourages every Publicity to, when exercising its institutional or business role, to be also able to guide, develop and stimulate society aiming at a sustainable future." This Council intends to "reduce the space for uses of the 'sustainability' theme which can, somehow, trivialize or confuse the consumers", guiding the national advertising to obey "strictly to veracity, accuracy, pertinence and relevance criteria" (CONAR, 2011).

In the academic terms, the study approached the existing relations between Greenwashing and the Purchase Intention, showing the importance of marketing communication and the Consumer Confusion and Trust constructs involved in the conceptual model. It also presented the evaluation of the mediated relation with the use of procedure explained by Zhao et al. (2010) and expanded by Nitzl et al. (2016), aligned with the use of software SmartPLS 3.2.8. In managerial terms, the contribution of this study was to establish that the consumer, when noticing the Greenwashing practice, tends not to trust the product and the brand. Thus, the biggest challenges for companies are in taking actions that are surely reliable and that truly represent a concern with the environment, once the consumers are more attentive to such factors and less conducive to accepting the Greenwashing practice. Moreover, offering little information is not enough, or a slogan affirming it is an environmentally friendly company; it is necessary to carry out infrastructure investments and public relations actions to ensure the accuracy of information. It is important to demonstrate more and more that the product manufacturing process encompasses value and sustainability generation, involving everyone in the productive chain (Chan et al., 2012). It is also fundamental that the companies adopt a strategic green marketing orientation, including the entire organization and all aspects of the marketing mix (Dangelico \& Vocalelli, 2017; Papadas et al., 2017).

When returning to the research problem, it is possible to affirm that the Greenwashing practice refered to the analyzed product impacts directly in the Purchase Intention. It happens because it creates Confusion for the Consumer, who tends to distrust the ecological appeal. However, the use of a convenience sample as well as a cross-sectional study makes it difficult to generalizate the results, which is the limitation of the study. Also, the analyzed product further limits the study as it is a product intended for adults and not every adult consumes it. In the study, neither the satisfaction, loyalty or effect of the brand were evaluated, therefore, the analysis of the influence of the brand on behavioral intent when the product is analyzed from the perspective of green marketing and Greenwashing is suggested as future study.

\section{References}

Akturan, U. (2018). How does greenwashing affect green branding equity and purchase intention? An empirical research. Marketing Intelligence and Planning, 36(7), 809-824.

Ali, F., Rasoolimanesh, S. M., Sarstedt, M., Ringle, C. M., \& Ryu, K. (2018). An assessment of the use of partial least squares structural equation modeling ( PLS-SEM ) in hospitality research. International Journal of Contemporary Hospitality Management, 30(1), 514-538.

Bailey, A. A., Mishra, A., \& Tiamiyu, M. F. (2014). Green advertising receptivity: An initial scale development process. Journal of Marketing Communications, 22(3), 327-345.

Berrone, P., Fosfuri, A., \& Gelabert, L. (2015). Does Greenwashing Pay Off? Understanding the Relationship Between Environmental Actions and Environmental Legitimacy. Journal of Business Ethics, 144(2), 363-379.

Braga Junior, S., Martínez, M. P., Correa, C. M., Moura-Leite, R. C., \& Da Silva, D. (2019). Greenwashing effect, attitudes, and beliefs in green consumption. RAUSP Management Journal, 54(2), 226-241.

Brønn, P. S. (2011). Marketing and Corporate Social Responsibility. In The Handbook of communication and corporate social responsibility (p. 601).

Chan, H. K., He, H., \& Wang, W. Y. C. (2012). Green marketing and its impact on supply chain management in industrial markets. Industrial Marketing Management, 41(4), 557-562.

Chen, Y. S., \& Chang, C. H. (2013). Greenwash and Green Trust: The Mediation Effects of Green 
Consumer Confusion and Green Perceived Risk. Journal of Business Ethics, 114(3), 489-500.

Chen, Y. S., Huang, A. F., Wang, T. Y., \& Chen, Y. R. (2018). Greenwash and green purchase behaviour: the mediation of green brand image and green brand loyalty. Total Quality Management and Business Excellence, 31(1-2), 194-209.

Cohen, J. (1988). Statistical power analysis for the behavioral sciences. Lawrence Earlbaum Associates.

Colquitt, J. A., Scott, B. A., \& LePine, J. A. (2007). Trust, Trustworthiness, and Trust Propensity: A MetaAnalytic Test of Their Unique Relationships With Risk Taking and Job Performance. Journal of Applied Psychology, 92(4), 909-927.

CONAR. (2011). Código Brasileiro de Autorregulamentação Publicitária. http://www.conar.org.br/codigo/codigo.php

Cooper, D R.; Schindler, P. S. (2016). Métodos de Pesquisa em Administração (12 th). AMGH Editora Ltda.

Correa, C. M., Machado, J. G. de C. F., \& Braga Junior, S. S. (2018). A Relação do Greenwashing com a Reputação da Marca e a Desconfiança do Consumidor. Revista Brasileira de Marketing, 17(04), 590-602.

Dangelico, R. M., \& Vocalelli, D. (2017). "Green Marketing”: An analysis of definitions, strategy steps, and tools through a systematic review of the literature. Journal of Cleaner Production, 165, 12631279.

Dean, T. J., \& Pacheco, D. F. (2014). Green marketing: A strategic balancing act for creating value. Journal of Business Strategy, 35(5), 14-22.

DeVellis, R. F. (2003). Scale Development, Theory and Applications. Sage Publications, Inc.

Dias, R. (2011). Gestão ambiental: responsabilidade social e sustentabilidade (2nd ed.). Editora Atlas S.A.

Edmonds, W. A; Kennedy, T. D. (2017). An Applied Guide to Research Designs: Quantitative, Qualitative, and Mixed Methods (2nd ed.). Sage Publications, Inc.

Fornell, C., \& Larcker, D. F. (1981). Structural Equation Models with Unobservable Variables and Measurement Error: Algebra Structural Equation Models With. Journal of Marketing Research, 18(3), 382-388.

Fraccascia, L., Giannoccaro, I., \& Albino, V. (2018). Green product development: What does the country product space imply? Journal of Cleaner Production, 170, 1076-1088.

Ghoshal, M. (2011). Green marketing- A changing concept in changing time. Management Edge, 4(1), 82-92.

Goh, S. K., \& Balaji, M. S. (2016). Linking green skepticism to green purchase behavior. Journal of Cleaner Production, 131, 629-638.

Groening, C., Sarkis, J., \& Zhu, Q. (2018). Green marketing consumer-level theory review: A compendium of applied theories and further research directions. Journal of Cleaner Production, $172,1848-1866$.

Grove, S. J., \& Kangun, N. (1993). A content analysis of environmental advertising claims: A matrix method approach les carlson. Journal of Advertising, 22(3), 27-39.

Hair, J F.; Babin, B; Money, A H.; Samouel, P. (2005). Fundamentos de Métodos de Pesquisa em Administração. Bookman.

Hair, J F.; Black, W C; Babin, B J.; Anderson, R E.; Tatham, R. L. (2009). Análise Multivariada de Dados (6th ed.). Bookman.

Hair, J. F., Hult, G. T. M., Ringle, C. M., \& Sarstedt, M. (2017). A Primer on Partial Least Squares Structural Equation Modeling (2nd ed.). Sage Publications, Inc.

Hair, J. F., Sarstedt, M., Ringle, C. M., \& Gudergan, S. P. (2018). Advanced Issues in Partial Least Squares Structural Equation Modeling. Sage Publications, Inc.

Hasan, Z., \& Ali, N. A. (2015). The Impact of Green Marketing Strategy on the Firm's Performance in Malaysia. Procedia - Social and Behavioral Sciences, 172, 463-470.

Henseler, J., Hubona, G., \& Ray, P. A. (2016). Using PLS path modeling in new technology research: Updated guidelines. Industrial Management and Data Systems, 116(1), 2-20.

Henseler, J., Ringle, C. M., \& Sarstedt, M. (2015). A new criterion for assessing discriminant validity in variance-based structural equation modeling. Journal of the Academy of Marketing Science, 43(1), 115-135. 
Henseler, J., Ringle, C. M., \& Sinkovics, R. R. (2009). The use of partial least squares path modeling in international marketing. In R. R. Sinkovics \& P. N. Ghauri (Eds.), New Challenges to International Marketing (Vol. 20, pp. 277-319). Emerald Group Publishing Limited.

Kurpierz, J. R., \& Smith, K. (2020). The greenwashing triangle: adapting tools from fraud to improve CSR reporting. Sustainability Accounting, Management and Policy Journal.

Leonidou, C. N., \& Skarmeas, D. (2015). Gray Shades of Green: Causes and Consequences of Green Skepticism. Journal of Business Ethics, 144(2), 401-415.

Li, Y., Ye, F., Sheu, C., \& Yang, Q. (2018). Linking green market orientation and performance: Antecedents and processes. Journal of Cleaner Production, 192, 924-931.

Lima, E. B. de, Costa, C. S. R., \& Félix, G. R. (2019). Emoções Culpa e Orgulho e Sua Influência na Intenção de Compra de Produtos Verdes. Consumer Behavior Review, 3(2), 70-84.

Lopes, V. N., \& Pacagnan, M. N. (2014). Marketing verde e práticas socioambientais nas indústrias do Paraná. Revista de Administração, 49(1), 116-128.

Lu, L., Bock, D., \& Joseph, M. (2013). Green marketing: What the Millennials buy. Journal of Business Strategy, 34(6), 3-10.

Malhotra, N. K. (2019). Pesquisa de Marketing. Bookman.

Martínez, P. (2015). Customer loyalty: Exploring its antecedents from a green marketing perspective. International Journal of Contemporary Hospitality Management, 27(5), 896-917.

Matzler, K., Stieger, D., \& Füller, J. (2011). Consumer Confusion in Internet-Based Mass Customization: Testing a Network of Antecedents and Consequences. Journal of Consumer Policy, 34(2), 231-247.

McAllister, D. J. (1995). Affect- and Cognition-Based Trust As Foundations for Interpersonal Cooperation in Organizations. Academy of Management Journal, 38(1), 24-59.

Mitchell, V. W., \& Papavassiliou, V. (1999). Marketing causes and implications of consumer confusion. Journal of Product \& Brand Management, 8(4), 319-342.

Mitchell, V. W., Walsh, G., \& Yamin, M. (2005). Towards a Conceptual Model of Consumer Confusion. Advances in Consumer Research, 32(1), 143-150.

Montague, J., \& Mukherjee, A. (2010). Marketing Green Products: What Really Matters? Proceedings of the Northeast Business \& Economics Association, 433-441.

Moorman, C., Zaltman, G., \& Deshpande, R. (2011). Relationships between Providers and Users of Market Research: The Dynamics of Trust within and between Organizations. Journal of Marketing, 29(3), 314-328.

Nascimento, T. M. (2019). Examinando o Domínio do Comportamento Pró-Ambiental na Promoção do Bem-Estar Individual e Coletivo. Consumer Behavior Review, 3(1), 27-41.

Nitzl, C., Roldan, J. L., \& Cepeda, G. (2016). Mediation analysis in partial least squares path modelling: Helping researchers discuss more sophisticated models. Industrial Management and Data Systems, 116(9), 1849-1864.

Paço, A. M. F., Raposo, M. L. B., \& Filho, W. L. (2009). Identifying the green consumer: A segmentation study. Journal of Targeting, Measurement and Analysis for Marketing, 17(1), 17-25.

Paço, A. M. F., Shiel, C., \& Alves, H. (2019). A new model for testing green consumer behaviour. Journal of Cleaner Production, 207, 998-1006.

Papadas, K. K., Avlonitis, G. J., \& Carrigan, M. (2017). Green marketing orientation: Conceptualization, scale development and validation. Journal of Business Research, 80(May), 236-246.

Papadopoulos, I., Karagouni, G., Trigkas, M., \& Platogianni, E. (2010). Green marketing the case of greece in certified and sustainably managed timber products. EuroMed Journal of Business, 5(2), 166-190.

Parguel, B., Benoît-Moreau, F., \& Larceneux, F. (2011). How Sustainability Ratings Might Deter "Greenwashing": A Closer Look at Ethical Corporate Communication. Journal of Business Ethics, 102(1), 15-28.

Parguel, B., Benoit-Moreau, F., \& Russell, C. A. (2015). Can evoking nature in advertising mislead consumers? The power of 'executional greenwashing.' International Journal of Advertising, 34(1), 107-134.

Peattie, K. (2001). Towards Sustainability: The Third Age of Green Marketing. The Marketing Review, 2(2), 129-146. 
Pereira, G. R., Veiga, A. R., Oliveira Júnior, J. C., \& Oliveira, H. C. (2017). Marketing Verde: Fatores da Geração Z sobre Questões Ambientais. Consumer Behavior Review, 1(2), 58-72.

Polonsky, M. J. (1994). An Introduction To Green Marketing. Electronic Green Journal, 1(2), 1-11.

Polonsky, M. J. (2011). Transformative green marketing: Impediments and opportunities. Journal of Business Research, 64(12), 1311-1319.

Rahman, I., Park, J., \& Chi, C. G. (2015). Consequences of "greenwashing." International Journal of Contemporary Hospitality Management, 27(6), 1054-1081.

Ringle, C. M., Silva, D., \& Bido, D. S. (2014). Structural Equation Modeling with the Smartpls. Revista Brasileira de Marketing, 13(02), 56-73.

Romero, P. (2008). Beware of green marketing, warns Greenpeace exec. Https://News.AbsCbn.Com/Special-Report/09/16/08/Beware-Green-Marketing-Warns-Greenpeace-Exec.

Rousseau, D. M., Sitkin, S. B., Burt, R. S., \& Camerer, C. (1998). Not so different after all: A crossdiscipline view of trust. Academy of Management Review, 23(3), 393-404.

Simão, L., \& Lisboa, A. (2017). Green Marketing and Green Brand - The Toyota Case. Procedia Manufacturing, 12(December 2016), 183-194.

Sirdeshmukh, D., Singh, J., \& Sabol, B. (2002). Consumer Trust, Value, and Loyalty in Relational Exchanges. Journal of Marketing, 66(1), 15-37.

Smith, K. T., \& Brower, T. R. (2012). Longitudinal study of green marketing strategies that influence Millennials. Journal of Strategic Marketing, 20(6), 535-551.

Terres, M. da S., Santos, C. P. dos, \& Basso, K. (2015). Antecedents of the client's trust in low- versus high-consequence decisions. Journal of Services Marketing, 29(1), 26-37.

Turnbull, P. W., Leek, S., \& Ying, G. (2000). Customer Confusion: The Mobile Phone Market. Journal of Marketing Management, 16(1-3), 143-163.

Wang, D., Walker, T., \& Barabanov, S. (2020). A psychological approach to regaining consumer trust after greenwashing: the case of Chinese green consumers. Journal of Consumer Marketing, 18.

Wang, H., Ma, B., \& Bai, R. (2019). The spillover effect of greenwashing behaviours: an experimental approach. Marketing Intelligence and Planning, 91746210.

Yadav, R., \& Pathak, G. S. (2017). Determinants of Consumers' Green Purchase Behavior in a Developing Nation: Applying and Extending the Theory of Planned Behavior. Ecological Economics, 134, 114-122.

Young, L. (2006). Trust: Looking forward and back. Journal of Business and Industrial Marketing, 21(7), 439-445.

Zhang, L., Li, D., Cao, C., \& Huang, S. (2018). The influence of greenwashing perception on green purchasing intentions: The mediating role of green word-of-mouth and moderating role of green concern. Journal of Cleaner Production, 187, 740-750.

Zhao, X., Lynch, J. G., \& Chen, Q. (2010). Reconsidering Baron and Kenny: Myths and Truths about Mediation Analysis. Journal of Consumer Research, 37(2), 197-206.

Zhu, Q., \& Sarkis, J. (2006). An inter-sectoral comparison of green supply chain management in China: Drivers and practices. Journal of Cleaner Production, 14(5), 472-486.

Zinkhan, G. M., \& Carlson, L. (1995). Green Advertising and the Reluctant Consumer The Greening of Corporate America. Journal of Advertising, 24(2), 1-6. 